\title{
Salivary Gland Tumors: A 15- year Report from Iran
}

\author{
Nasim TAGHAVI', Soudabeh SARGOLZAEI', Fatemeh MASHHADIABBAS' ${ }^{1}$, Alireza AKBARZADEH ${ }^{2}$, \\ Parisa KARDOUNI' \\ 'Department of Oral Pathology, Shahid Beheshti University of Medical Sciences, TEHRAN, IRAN \\ 2Department of Basic Sciences, School of Rehabilitation, Shahid Beheshti University of Medical Sciences, TEHRAN, IRAN
}

\begin{abstract}
Objective: The aim of this study was to document the clinicopathologic characteristic of salivary gland tumors in Tehran, Iran, over a 15-year period.

Material and Method: A retrospective study was conducted on salivary gland tumors diagnosed at two pathology centers of Shahid Beheshti University of Medical Sciences from March 2000 to March 2015. Patient age, sex, tumor site and frequency, as well as clinical and radiographic features and histopathologic diagnosis constituted the main analysis outcome measures.

Results: Of the 45429 biopsies conducted over 15 years, 6065 (13.3\%) cases were oral and maxillofacial lesions and 937 (15.4\%) of these had tumoral diagnoses. Of the 937 tumoral cases, 184 (19.6\%) were salivary gland tumors and among 184 cases, 65 (35.3\%) were benign and $119(64.7 \%)$ were malignant. Pleomorphic adenoma was the most frequently occurring tumor, comprising $32.6 \%$ of all tumors, followed by mucoepidermoid carcinoma (27.1\%) and adenoid cystic carcinoma (22.2\%). Tumors were frequently reported in minor salivary glands (75\%), particularly in the palate with $89(48.4 \%)$ cases. The peak ages of incidence were the fourth and sixth decades of life. Malignant salivary gland tumors showed a predilection for females $(72.9 \%)$, which was statistically significant $(\mathrm{P}<0.01)$.
\end{abstract}

Conclusion: The data presented herein are similar to previously published reports in other countries and other areas of Iran. However, some differences were observed in our study, such as higher overall frequency, a lower mean age of patients with malignant tumors, and the particular sites of involvement. These differences can be attributed to racial factors, the pathology centers of sample collection, and the duration of the studies.

Key Words: Salivary gland,Tumor, Iran

\section{INTRODUCTION}

The salivary gland system is composed of three pairs of major glands and many lobules of minor salivary glands that are scattered in the upper aero digestive tract, especially in the oral cavity (1). Salivary gland neoplasms, though uncommon, are remarkable for their diverse and complex histologic features and various behaviors and prognoses. These tumors account for 3-6\% of all head and neck tumors (2). Less than $5 \%$ of salivary gland neoplasms occur in patients under 16 years of age (3).

Epidemiologic studies have shown that the incidence and subgroup distributions of salivary gland neoplasms vary across the world, with diverse demographic results in different regions.

The aim of the present study was to evaluate the epidemiologic characteristics of salivary gland tumors (SGTs) during a 15-year period in Tehran, Iran based on the 2005 WHO classification. Select data that are available

(Turk Patoloji Derg 2016, 32:35-39)

Received : 13.08.2015 Accepted : 20.10.2015 from other provinces in Iran and other countries are also compared and discussed.

\section{MATERIAL and METHODS}

The data in this retrospective and descriptive study included records of the following 2 referral pathology centers of Shahid Beheshti University of Medical Sciences in Tehran, Iran: (a) the Oral and Maxillofacial Pathology Department and (b) the Taleghani hospital. Patient records from March 2000 to March 2015, in which SGTs were diagnosed, were reviewed.

Patient age, sex, tumor site and frequency, as well as clinical, radiographic feature and histopathologic diagnosis constituted the main analysis outcome measures. All data was anonymous prior to analysis. This research was approved by the ethics committee of Shahid Beheshti University of Medical Sciences. Data were analyzed using SPSS software (version 11.5).

Correspondence: Nasim TAGHAVI

Shahid Beheshti University of Medical Sciences,

Department of Oral Pathology, TEHRAN, IRAN

E-mail: nasimtaghavi46@gmail.com Phone: +989121815387 


\section{RESULTS}

Of the 45429 biopsies conducted over 15 years, 6065 $(13.3 \%)$ cases were oral and maxillofacial lesions, and 937 (15.4\%) of these had tumoral diagnoses. Of the 937 tumoral cases, $184(19.6 \%)$ cases were SGTs. The overall frequencies of benign and malignant tumors were 35.3\% and $64.7 \%$, respectively. Pleomorphic adenoma (PA) was the most frequently occurring tumor, comprising 60 cases, $32.6 \%$ of all tumors and $92.3 \%$ of benign neoplasms. Mucoepidermoid carcinoma (MEC) was the most frequently occurring malignancy and the second most common tumor, representing $27.1 \%$ of all tumors and $42.01 \%$ of malignant tumors. There were 41 cases of adenoid cystic carcinoma (ADCC) (22.2\% of all tumors), which made it the third most frequent tumor and the second most common malignant tumor (34.4\% of malignant tumors). Tumors were more frequently reported in minor salivary glands (73.9\%), particularly the palate with 89 (48.4\%) cases, followed by the parotid (14.6\%).

Table I shows the distribution and location of the individual neoplasms. Eight cases of intraosseous MEC (16\% of all MECs and $4.3 \%$ of all cases considered) were identified in our series, and these cases mainly affected women (62.5\%) and particularly the posterior of the mandible (5 cases) for patients with a mean age of 40.5 years. Interestingly, all cases of acinic cell carcinoma were diagnosed during the second decade of life.

Regarding location, Fischer's exact test showed no significant difference between benign and malignant tumors $(\mathrm{p}=0.301)$.

In terms of gender, $111(60.4 \%)$ cases were female and 73 (39.6\%) cases were male. Benign tumors showed a slight predilection for males (53.8\%), whereas malignant tumors showed a predilection for females (72.9\%). This difference was statistically significant $(\mathrm{p}<0.01)$ and represented the higher malignancy predilection in females.

The peak ages of incidence were the fourth and sixth decades of life with mean ages of 41.2 and 45.5 years for benign and malignant tumors, respectively (Table II). T-test on individual samples revealed no significant difference between the mean ages of benign and malignant tumors $(\mathrm{p}=0.148)$.

The most significant sign of benign tumors was a painless swelling, while rapid growth and ulcerative surface were noted in malignant cases and especially high-grade tumors. In 24 ADCC cases, the first significant sign was pain, which has been associated with perineural invasion on pathological evaluation.

Table I: Distribution and locations of benign and malignant salivary gland tumors

\begin{tabular}{|l|c|c|c|c|c|c|}
\hline Tumors & $\begin{array}{c}\text { PG } \\
\mathbf{n}(\%)\end{array}$ & $\begin{array}{c}\text { SMG } \\
\mathbf{n}(\%)\end{array}$ & $\begin{array}{c}\text { SLG } \\
\mathbf{n}(\%)\end{array}$ & $\begin{array}{c}\text { MSG } \\
\mathbf{n}(\%)\end{array}$ & $\begin{array}{c}\text { Intraosseous } \\
\mathbf{n}(\%)\end{array}$ & $\begin{array}{c}\text { Total } \\
\mathbf{n}\end{array}$ \\
\hline Benign (n=65) & $10(5.4 \%)$ & $3(1.63 \%)$ & - & $47(25.5 \%)$ & - & $60(32.6 \%)$ \\
\hline Pleomorphic adenoma & $1(0.54 \%)$ & - & - & - & - & $1(0.54 \%)$ \\
\hline Basal cell adenoma & $1(0.54 \%)$ & - & - & - & - & $1(0.54 \%)$ \\
\hline Warthin's tumor & $1(0.54 \%)$ & - & - & $2(1.08 \%)$ & - & $3(1.63 \%)$ \\
\hline Myoepithelioma & $5(2.7 \%)$ & $3(1.63 \%)$ & $1(0.54 \%)$ & $33(17.9 \%)$ & $8(4.3 \%)$ & $50(27.1 \%)$ \\
\hline Malignant (n=1 19) & $2(1.08 \%)$ & $0(0 \%)$ & $1(0.54 \%)$ & $38(20.6 \%)$ & $0(0 \%)$ & $41(22.2 \%)$ \\
\hline Mucoepidermoid carcinoma & $4(2.1 \%)$ & $1(0.54 \%)$ & $1(0.54 \%)$ & $5(2.7 \%)$ & $0(0 \%)$ & $11(5.9 \%)$ \\
\hline Adenoid cystic carcinoma & $1(0.54 \%)$ & $1(0.54 \%)$ & $0(0 \%)$ & $3(1.63 \%)$ & $0(0 \%)$ & $5(2.7 \%)$ \\
\hline Adenocarcinoma not otherwise specified & $0(0 \%)$ & $0(0 \%)$ & $0(0 \%)$ & $1(0.54 \%)$ & $0(0 \%)$ & $1(0.54 \%)$ \\
\hline Carcinoma ex- pleomorphic adenoma & $0(0 \%)$ & $0(0 \%)$ & $0(0 \%)$ & $3(1.63 \%)$ & $0(0 \%)$ & $3(1.63 \%)$ \\
\hline Hyalinizing clear cell carcinoma & $1(0.54 \%)$ & $0(0 \%)$ & $0(0 \%)$ & $2(1.08 \%)$ & $0(0 \%)$ & $3(1.63 \%)$ \\
\hline Polymorphous low-grade adenocarcinoma & $0(0 \%)$ & $0(0 \%)$ & $0(0 \%)$ & $1(0.54 \%)$ & $0(0 \%)$ & $1(0.54 \%)$ \\
\hline Acinic cell carcinoma & $1(0.54 \%)$ & $0(0 \%)$ & $0(0 \%)$ & $3(1.63 \%)$ & $0(0 \%)$ & $4(2.1 \%)$ \\
\hline Undifferentiated carcinoma & $\mathbf{2 7}(\mathbf{1 4 . 7 \% )}$ & $\mathbf{8 ( 4 . 3 \% )}$ & $\mathbf{3 ( 1 . 7 \% )}$ & $\mathbf{1 3 8 ( 7 5 \% )}$ & $\mathbf{8 ( 4 . 3 \% )}$ & $\mathbf{1 8 4}(\mathbf{1 0 0} \%)$ \\
\hline Salivary duct carcinoma
\end{tabular}

PG: Parotid gland, SMG: Submandibular gland, SLG: Sublingual gland, MSG: Minor salivary gland. 
Table II: Age and sex distributions of salivary gland tumors

\begin{tabular}{|c|c|c|c|c|c|c|c|c|}
\hline \multirow[b]{2}{*}{ Tumor } & \multicolumn{8}{|c|}{ Age $(y)$ and sex $(M / F)$} \\
\hline & $\begin{array}{c}0-9 \\
0(0 \%)\end{array}$ & $\begin{array}{c}10-19 \\
10(5.4 \%)\end{array}$ & $\begin{array}{c}20-29 \\
12(6.5 \%)\end{array}$ & $\begin{array}{c}30-39 \\
46(25 \%)\end{array}$ & $\begin{array}{c}40-49 \\
25(13.6 \%)\end{array}$ & $\begin{array}{c}50-59 \\
60(32.6 \%)\end{array}$ & $\begin{array}{c}60-69 \\
20(10.9 \%)\end{array}$ & $\begin{array}{c}70-79 \\
11(6 \%) \\
\end{array}$ \\
\hline Pleomorphic adenoma & - & $1 / 2$ & $3 / 2$ & $13 / 4$ & $7 / 1$ & $5 / 11$ & $2 / 4$ & $2 / 3$ \\
\hline Mucoepidermoid carcinoma & - & $1 / 3$ & $3 / 1$ & $4 / 10$ & $4 / 5$ & $1 / 7$ & $1 / 5$ & $1 / 4$ \\
\hline Adenoid cystic carcinoma & - & - & $1 / 1$ & $6 / 2$ & $1 / 5$ & $4 / 18$ & $0 / 2$ & $0 / 1$ \\
\hline Adenocarcinoma & - & - & - & $1 / 2$ & - & $1 / 2$ & $1 / 4$ & - \\
\hline Salivary duct carcinoma & - & - & - & - & $2 / 0$ & $2 / 0$ & - & - \\
\hline $\begin{array}{l}\text { Carcinoma ex-pleomorphic } \\
\text { adenoma }\end{array}$ & - & - & - & $0 / 1$ & - & $2 / 2$ & - & - \\
\hline Acinic cell carcinoma & - & $1 / 2$ & - & - & - & - & - & - \\
\hline $\begin{array}{l}\text { Hyalinizing clear cell } \\
\text { carcinoma }\end{array}$ & - & - & - & - & - & $0 / 1$ & - & - \\
\hline $\begin{array}{l}\text { Polymorphous low- grade } \\
\text { adenocarcinoma }\end{array}$ & - & - & - & - & - & $1 / 1$ & $0 / 1$ & - \\
\hline Basal cell adenoma & - & - & - & - & $0 / 1$ & - & - & - \\
\hline Myoepithelioma & - & - & $0 / 1$ & $1 / 1$ & - & - & - & - \\
\hline Undifferentiated carcinoma & - & - & - & - & - & $0 / 1$ & - & - \\
\hline Warthin's tumor & - & - & - & - & - & $1 / 0$ & - & - \\
\hline Total & - & $3 / 7$ & $7 / 5$ & $25 / 21$ & $14 / 11$ & $17 / 43$ & $4 / 16$ & $3 / 8$ \\
\hline
\end{tabular}

The predominant radiographic feature of intraosseous MECs was ill-defined multilocular radiolucency.

\section{DISCUSSION}

The present study profiles SGTs in Tehran, Iran, according to the 2005 WHO classification using cases taken from two large university pathology centers over a 15 -year period. Of the 45429 biopsies reported, 184 cases $(0.4 \%)$ were SGTs. In previous reports from other Iranian, Nigerian and Mexican groups, the percentages of SGT cases were $2.7 \%, 0.4 \%$ and $0.2 \%$, respectively. (4-6).

Moreover, the cases of SGTs evaluated in this study constituted $19.6 \%$ of the oral and maxillofacial tumors encountered, in contrast to the much lower ratios $(4.5 \%, 2 \%)$ reported by other researchers $(2,7,8)$. However, it is noteworthy that Pour et al. (9) reported a ratio of $26.1 \%$ for malignant SGTs in head and neck tumors.

The present study's evaluation of 184 S GT cases indicates that the majority of tumors were malignant, in contrast to the results of most studies in west and south Iran and other countries $(1,4,6,10-13)$ and in agreement with a few studies $(14,15)$.
In agreement with the results of Masanja et al. (11), Ansari et al. (16) and Laishram et al. (2), we found an overall higher frequency in females versus males which was statistically significant. It should be considered that the male-to-female ratio of benign tumors was 1.06: 1, whereas malignant tumors had a male-to-female ratio of 0.45 : 1 , indicating that benign tumors were slightly more common in males and malignancies were more common in females. These results are in agreement with previous studies of Tunisian and Nigerian populations $(5,17)$, but are in contrast to previously reported results in Brazilian, Turkish, Mexican and Chinese populations $(6,10,18,19)$.

The patients' ages in current study varied from 11 to 79 years old, with a mean age of 41.2 years, in agreement with other studies $(1,6,10,16,19)$. The mean age of patients with malignant tumors did not differ significantly from the mean age of patients with benign tumors, indicating that the mean age of patients with malignant tumors had been lowered in our series and the tumors can be seen in younger patients, as found by Jansisyanont et al. (20).

Most SGT cases $(73.9 \%)$ originated in the minor salivary glands, demonstrating a high frequency in the palate (48.4\%). The parotid (14.6\%) was the second most common SGT site, which is consistent with some previous 
reports $(8,14,15)$ but not with others $(1,4,5,13,19,21-23)$. In addition, 8 cases $(4.3 \%)$ of central MEC were observed in the present study and these mainly affected women $(62.5 \%)$ having a mean age of 40.5 years, similar to the $\mathrm{Li}$ et al. report (24). Moreover, the present study confirmed previous reports that PA (32.6\%) was the most frequently occurring type of SGT $(1,2,4-6,10-13,16,19,21,25)$. The next most frequently occurring tumor types were MEC $(27.1 \%)$ and ADCC $(22.2 \%)(13,14,16,19,26)$. In contrast, in the Velazquez et al. and Wang et al. studies, Warthin's tumor was the second most common tumor, followed by malignant tumors $(6,21)$. In studies of populations in the Congo, Jordan and Croatia, ADCC and MEC comprised the second and third most common tumors, respectively $(22,27,28)$. However, Kamulegeya et al. studied an Ugandian population and found that adenocarcinoma was the most common malignant tumor (29). In the present series, adenocarcinoma constituted $5.9 \%$ of the SGTs encountered.

The most predominant clinical sign of benign tumors in the present study was painless expansion, while pain, rapid growth and ulcerative surface were observed in malignant tumors, in accordance with previous studies $(2,3,9,30)$.

In conclusion, the data and results presented herein were similar to previously published reports in other countries and other areas of Iran. However, some differences were observed, such a higher overall frequency, a lower mean age of patients with malignant tumors and the particular sites of involvement in our study. These differences can be attributed to racial factors, the pathology centers of sample collection and the duration of the studies.

\section{REFERENCES}

1. Shishegar M, Ashraf MJ, Azarpira N, Khademi B, Hashemi B, Ashrafi A. Salivary gland tumors in maxillofacial region: A retrospective study of 130 cases in a Southern Iranian population. Patholog Res Int. 2011;2011:934350.

2. Laishram RS, Kumar KA, Pukhrambam GD, Laishram S, Debnath K. Pattern of salivary gland tumors in Manipur, India: A 10 year study. South Asian J Cancer. 2013;2:250-3.

3. Bello IO, Salo T, Dayan D, Tervahauta E, Almangoush A, Schnaiderman-Shapiro A, Barshack I, Leivo I, Vered M. Epithelial salivary gland tumors in two distinct geographical locations, Finland (Helsinki and Oulu) and Israel (Tel Aviv): A 10-year retrospective comparative study of 2, 218 cases. Head Neck Pathol. 2012;6:224-31.

4. Jaafari Ashkavandi Z, Ashraf MJ, Moshaverinia M. Salivary gland tumors: A clinicopathologic study of 366 cases in Southern Iran. Asian Pac J Cancer Prev. 2013;14:27-30.
5. Ochicha O, Malami S, Mohammed A, Atanda A. A histopathologic study of salivary gland tumors in Kano, northern Nigeria. Indian J Pathol Microbiol. 2009; 52:473-6.

6. Mejía-Velázquez CP, Durán-Padilla MA, Gómez-Apo E, Quezada-Rivera D, Gaitán-Cepeda LA. Tumors of the salivary gland in Mexicans. A retrospective study of 360 cases. Med Oral Patol Oral Cir Bucal. 2012;17:e183-9.

7. Lee WH, Tseng TM, Hsu HT, Lee FP, Hung SH, Chen PY. Salivary gland tumors: A 20-year review of clinical diagnostic accuracy at a single center. Oncol Lett. 2014;7:583-7.

8. Adeyemi BF, Ogun GO, Akang EE. Retrospective analysis of intra-oral salivary gland tumours in Ibadan, Nigeria. West Afr J Med. 2010;29:98-103.

9. Pour H, Zarei MR, Chamani G, Rad M. Malignant salivary glands tumors in Kerman Province: A retrospective study. Dental Research Journal 2007;4:4-10.

10. Kara MI, Göze F, Ezirganli S, Polat S, Muderris S, Elagoz S. Neoplasms of the salivary glands in a Turkish adult population. Med Oral Patol Oral Cir Bucal. 2010;15:e880-5.

11. Masanja MI, Kalyanyama BM, Simon EN. Salivary gland tumours in Tanzania. East Afr Med J. 2003;80:429-34.

12. Morais Mde L, Azevedo PR, Carvalho $\mathrm{CH}$, Medeiros L, Lajus $\mathrm{T}$, Costa Ade L. Clinicopathological study of salivary gland tumors: An assessment of 303 patients. Cad Saude Publica. 2011;27: 1035-40.

13. Subhashraj K. Salivary gland tumors: A single institution experience in India. Br J Oral Maxillofac Surg. 2008;46:635-8.

14. Tilakaratne WM, Jayasooriya PR, Tennakoon TM, Saku T. Epithelial salivary tumors in Sri Lanka: A retrospective study of 713 cases. Oral Surg Oral Med Oral Pathol Oral Radiol Endod. 2009;108:90-8.

15. Poomsawat S, Punyasingh J, Weerapradist W. A retrospective study of 60 cases of salivary gland tumors in a Thai population. Quintessence Int. 2004;35:577-81.

16. Ansari MH. Salivary gland tumors in an Iranian population: A retrospective study of 130 cases. J Oral Maxillofac Surg. 2007; 65:2187-94.

17. Moatemri R, Belajouza H, Farroukh U, Ommezzine M, Slama A, Ayachi S, Khochtali H, Bakir A. Epidemiological profile of salivary-gland tumors in a Tunisian Teaching Hospital. Rev Stomatol Chir Maxillofac. 2008;109:148-52.

18. Fonseca FP, CarvalhoMde V, de Almeida OP, Rangel AL, Takizawa MC, Bueno AG, Vargas PA. Clinicopathologic analysis of 493 cases of salivary gland tumors in a Southern Brazilian population. Oral Surg Oral Med Oral Pathol Oral Radiol. 2012;114:230-9.

19. Li LJ, Li Y, Wen YM, Liu H, Zhao HW. Clinical analysis of salivary gland tumor cases in West China in past 50 years. Oral Oncol. 2008; 44:187-92.

20. Jansisyanont P, Blanchaert RH Jr, Ord RA. Intraoral minor salivary gland neoplasm: A single institution experience of 80 cases. Int J Oral Maxillofac Surg. 2002; 31:257-6. 
21. Wang YL, Zhu YX, Chen TZ, Wang Y, Sun GH, Zhang L, Huang CP, Wang ZY, Shen Q, Li DS, Wu Y, Ji QH. Clinicopathologic study of 1176 salivary gland tumors in a Chinese population: Experience of one cancer center 1997-2007. Acta Otolaryngol. 2012;132:879-86.

22. Al-Khateeb TH, Ababneh KT. Salivary tumors in North Jordanians: A descriptive study. Oral Surg Oral Med Oral Pathol Oral Radiol Endod. 2007;103:e53-9.

23. Ergicho B, Ergisho B. Pattern of salivary gland tumors in Ethiopia and non-western countries. Ethiop Med J. 2003;41:235-44.

24. Li Y, Li LJ, Huang J, Han B, Pan J. Central malignant salivary gland tumors of the jaw: Retrospective clinical analysis of 22 cases. J Oral Maxillofac Surg. 2008;66:2247-53.

25. Otoh EC, Johnson NW, Olasoji H, Danfillo IS, Adeleke OA. Salivary gland neoplasms in Maiduguri, North-Eastern Nigeria. Oral Dis. 2005;11:386-91.
26. Targa-Stramandinoli R, Torres-Pereira C, Piazzetta CM, Giovanini AF, Amenábar JM. Minor salivary gland tumors: A 10year study. Acta Otorrinolaringol Esp. 2009;60:199-201.

27. Kayembe MK, Kalengayi MM. Salivary gland tumors in Congo (Zaire). Odontostomatol Trop. 2002;25:19-22.

28. Lukšić I, Virag M, Manojlović S, Macan D. Salivary gland tumours: 25 years of experience from a single institution in Croatia. J Craniomaxillofac Surg. 2012;40:e75-81

29. Kamulegeya A, Kasangaki A. Neoplasms of the salivary glands: A descriptive retrospective study of 142 cases-Mulago Hospital Uganda. J Contemp Dent Pract. 2004;5:16-27.

30. Sousa J, De Sa O. Salivary gland tumours: An analysis of 62 cases. Indian J Cancer. 2001; 38:38-45. 